\title{
Evaluation of groundwater quality and its suitability for drinking and agricultural use in the coastal stretch of Alappuzha District, Kerala, India
}

\author{
S. V. Sarath Prasanth • N. S. Magesh • \\ K. V. Jitheshlal $\cdot$ N. Chandrasekar • \\ K. Gangadhar
}

Received: 9 February 2012/ Accepted: 27 April 2012/Published online: 17 May 2012

(C) The Author(s) 2012. This article is published with open access at Springerlink.com

\begin{abstract}
Groundwater is an essential and vital component of any life support system. It is not only the basic need for human existence but also a vital input for all development activities. The present hydro-geochemical study was confined to the coastal belt of Alappuzha district, which lies in the coastal lowland division of Kerala. Groundwater quality and its suitability for irrigation and domestic purpose were examined by various physico-chemical parameters such as $\mathrm{pH}$, electrical conductivity, total dissolved solids, total hardness, calcium, magnesium, sodium, potassium, bicarbonate, sulfate, and chloride. These parameters were used to assess the suitability of groundwater for domestic purpose by comparing with the WHO and Indian standards. TDS, sodium adsorption ratio (SAR), and permeability index were used for irrigation suitability assessment. The sample analysis reveals that the groundwater is not entirely fit for drinking with respect to $\mathrm{pH}, \mathrm{EC}$, $\mathrm{Ca}^{2+}, \mathrm{Mg}^{2+}, \mathrm{Na}^{+}$, and $\mathrm{Cl}^{-}$. In some of the collected samples, the concentrations of these parameters exceed the permissible limits of WHO and ISI standards. Based on
\end{abstract}

S. V. Sarath Prasanth · N. S. Magesh · K. V. Jitheshlal (ه) .

N. Chandrasekar

Centre for Geotechnology, Manonmaniam Sundaranar

University, Tirunelveli 627 012, Tamilnadu, India

e-mail: laljithenviro@gmail.com

S. V. Sarath Prasanth

e-mail: sarathsvgeo@gmail.com

N. S. Magesh

e-mail: mageshissivan@gmail.com

N. Chandrasekar

e-mail: profncsekar@gmail.com

K. Gangadhar

Department of Geology, University College,

Trivandrum 695 034, Kerala, India
TDS and SAR almost all samples are suitable for irrigation purpose except a few locations, which show values beyond the permissible limits. $\mathrm{Ca}-\mathrm{Mg}-\mathrm{HCO}_{3}$ is the dominant water type in the study area. The sequence of the abundance of the major cations and anions is $\mathrm{Ca}>\mathrm{Na}>$ $\mathrm{Mg}>\mathrm{K}=\mathrm{HCO}_{3}>\mathrm{Cl}>\mathrm{SO}_{4}$. Based on the total hardness and TDS, $96 \%$ of groundwater samples are found suitable for drinking purpose.

Keywords Groundwater quality $\cdot$ Hydrochemical facies . SAR $\cdot$ Permeability index $\cdot$ GIS $\cdot$ Kerala

\section{Introduction}

Water is a chief natural resource essential for the existence of life and is a basic human entity. Water resources are harnessed for various purposes like drinking, agricultural, industrial, household, recreational, and environmental activities, etc. Groundwater is one of the major sources of drinking water all over the world (Bear 1979). Of the $37 \mathrm{Mkm}^{3}$ of freshwater estimated to be present on the earth, about $22 \%$ exists as groundwater, which constitutes about $97 \%$ of all liquid freshwater potentially available for human use (Foster 1998). There has been tremendous increase in the demand for fresh water due to over exploitation and growth in population. Since groundwater is a renewable natural resource and a valuable component of the ecosystem, it is vulnerable to natural and human impacts. It is estimated that approximately one-third of the world's population use groundwater for drinking (Nickson et al. 2005) and about one million people are directly dependent upon the groundwater resources in Asia alone (Foster 1995). In most parts of India, groundwater forms the major source of water 
supply for drinking and agricultural purposes. Quality of groundwater is equally important to its quantity owing to the suitability of water for various purposes. Groundwater quality data give important clues to the geologic history or rocks and indications of groundwater recharge, discharge and storage (Walton 1970). Variation in groundwater quality in an area is a function of physical and chemical parameters that are greatly influenced by geological formations and anthropogenic activities (Subramani et al. 2005; Schiavo et al. 2006; Magesh and Chandrasekar 2011; Krishna Kumar et al. 2011). According to Babiker et al. (2007), the chemistry of groundwater is not only related to the lithology of the area and the residence time the water is in contact with rock material, but also reflects inputs from the atmosphere, from soil and weathering as well as from pollutant sources such as mining, land clearance, saline intrusion, industrial and domestic wastes. Excessive irrigation activities also resulted in groundwater pollution in India (Pawar and Shaikh 1995; Sujatha and Reddy 2003). During the past 100 years, India's per capita water availability has decreased fourfold whereas for Kerala, it has decreased fivefold (Basak 1992). The over exploitation of groundwater in the coastal zones has detrimentally affected its quality and quantity and may result in negative water balance, triggering seawater intrusion.

Groundwater used for domestic and irrigation purposes can vary greatly in quality depending upon type and quantity of dissolved salts. It contains a wide variety of dissolved inorganic chemical constituents in various concentrations, resulting from chemical and biochemical interactions between water and the geological materials. Dissolved salts should be present in irrigation water in relatively small but significant amounts. They originate from dissolution or weathering of the rocks and soil, including dissolution of lime, gypsum and other slowly dissolved soil minerals.

Alappuzha coastal stretch has been selected for the present study, which is the only district in Kerala where domestic and irrigation requirement is harnessed from groundwater source on a large scale. This is one among the major coastal zones of the state, where the demand for groundwater resources has accelerated in recent period (CGWB 2007). Manjusree et al. 2009 studied the groundwater quality of the coastal aquifers of ChennamPallippuram panchayath (Alappuzha district) and assessed that the groundwater in the panchayath if fit for drinking and irrigational purpose. But, the spatial extent of groundwater suitability was not reported in any study. Hence, the present study was carried out to evaluate the spatial extent of groundwater quality and its suitability for drinking and agricultural uses in the coastal stretch of Alappuzha district.

\section{Study area}

The study area lies in Alappuzha district, which is one of the well-developed coastal districts in southern part of Kerala covering an area of $1,414 \mathrm{~km}^{2}$. The present study area lies between $76^{\circ} 32^{\prime}-76^{\circ} 42^{\prime} \mathrm{E}$ longitudes and $09^{\circ} 26^{\prime}-09^{\circ} 48^{\prime} \mathrm{N}$ latitudes and stretches about $30 \mathrm{~km}$ along the coast (Fig. 1). The study area is mainly drained by Pamba river and its tributaries viz. Achankovil and Manimala rivers. The minimum to maximum temperature in the study area ranges from 23 to $33{ }^{\circ} \mathrm{C}$, respectively. The study area experiences two seasons: southwest monsoon season (June-Sept); and northeast monsoon season (Oct-Dec). The average annual rainfall in the study area ranges between 2,180 to 3,484 mm and experiences a humid tropical climate.

The study area falls under the coastal lowland physiographic unit of Kerala. The charnockite, khondalite and granites form the basement and are overlain by laterite/ alluvial sediments. The coastal alluvium comprising of sand and clay and the major abstraction of groundwater is from tertiary sedimentary formation (CGWB 2007). The borehole lithology at Pallippuram (Lat. $09^{\circ} 44^{\prime} 48^{\prime \prime} \mathrm{N}$ and Long. $76^{\circ} 21^{\prime} 53^{\prime \prime} \mathrm{E}$ ) indicates that the unconsolidated Quaternary sediments comprising sands constitute the upper layer underlain by clay, clayey sand, laterites, clay with limestone, clay with few sand, sandy clay, etc. (Fig. 2).

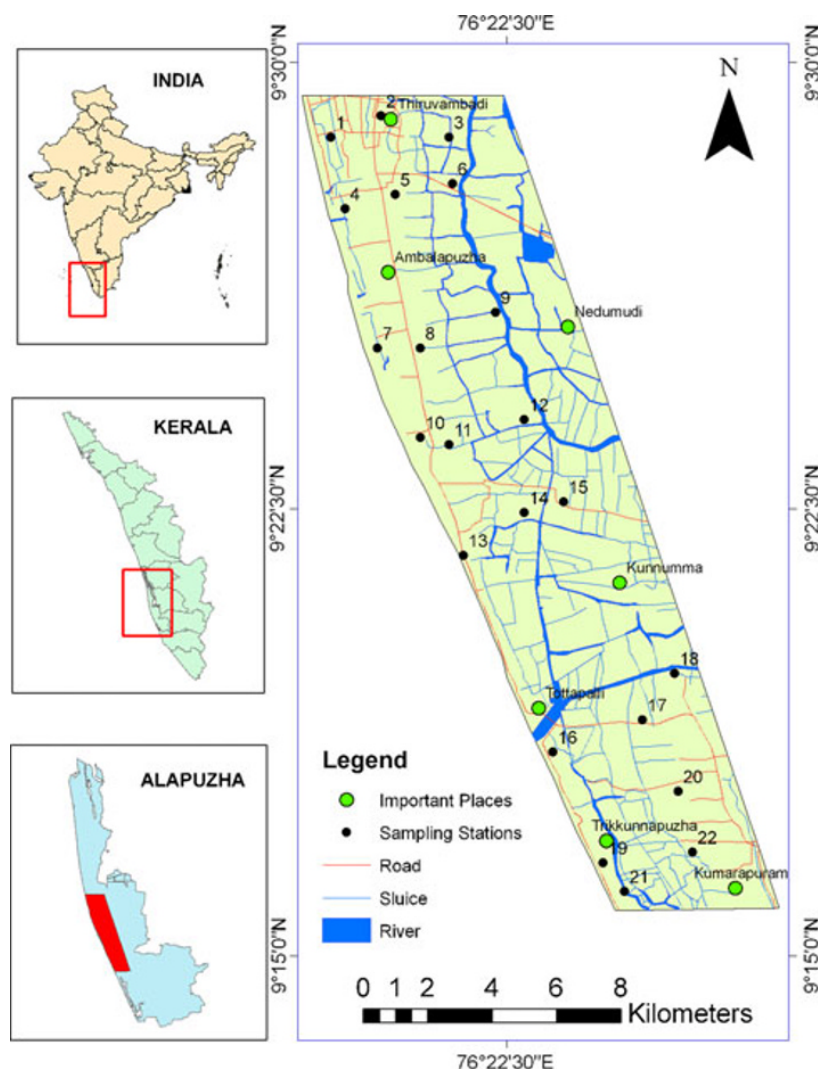

Fig. 1 Location map of the study area 
However, towards the coastal side (western part), the Quaternary sedimentary sequence, consisting of alternate layers of sand and clay, has a total depth of $445 \mathrm{~m}$ at Arthungal (Lat. $09^{\circ} 39^{\prime} 32^{\prime \prime} \mathrm{N}$ and Long. $76^{\circ} 17^{\prime} 59^{\prime \prime} \mathrm{E}$ ) (Manjusree et al. 2009).

\section{Methodology}

The base map of the study area were scanned and digitized from the Survey of India (SOI) Toposheets No. 58C/7 and $58 \mathrm{C} / 11(1: 50,000)$. ArcGIS ${ }^{\circledR} 10$ is used to map and analyze the data for the evaluation of groundwater quality. The area was equally divided into 21 grids for facilitating representative groundwater sample collection from the area and for assessing its suitability for domestic and irrigation purposes.

Groundwater samples were collected from 22 shallow open dug wells during January (2009) representing the post monsoon season. The location of sampling points is shown in Fig. 1. High-density polyethylene (HDPE) bottles were used for sample collection. The samples were filled up to the brim and were immediately sealed to avoid exposure to air and were labeled systematically. The labeled samples were analyzed in the laboratory for various physicochemical parameters. During sample collection, (handling and preservation) standard procedures recommended by the American Public Health Association (APHA 1995) were followed to ensure data quality and consistency.

The $\mathrm{pH}$ and electrical conductivity (EC) were measured in situ by using Hanna (HI9828 USA) multi-parameter probe and the major ions $\left(\mathrm{Ca}, \mathrm{Mg}, \mathrm{Na}, \mathrm{K}, \mathrm{HCO}_{3}, \mathrm{SO}_{4}, \mathrm{Cl}\right)$

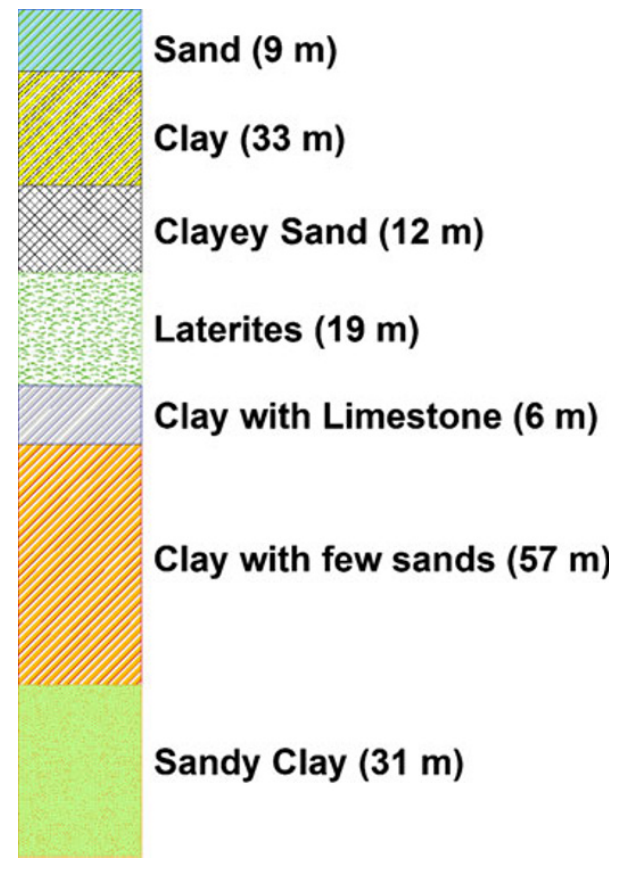

Fig. 2 Cross section of the under laying lithology were analyzed using the standard methods suggested by the American Public Health Association (APHA 1995). Among the analyzed ions, sodium (Na) and potassium (K) were determined by using flame photometer. Total hardness $(\mathrm{TH})$ as $\mathrm{CaCO}_{3}$, calcium $\left(\mathrm{Ca}^{2+}\right)$, magnesium $\left(\mathrm{Mg}^{2+}\right)$, bicarbonate $\left(\mathrm{HCO}_{3}{ }^{-}\right)$and chloride $(\mathrm{Cl})$ were analyzed by volumetric methods and sulfates $\left(\mathrm{SO}_{4}{ }^{2-}\right)$ were estimated by using the colorimetric method. The hydrochemical facies (Piper diagram) and the Wilcox plot in the study area were plotted using AquaChem 4.0 software.

The suitability of groundwater for agricultural and domestic purposes were evaluated by comparing the values of different water quality parameters with those of the World Health Organisation (WHO 2004) and Indian standard specification (ISI 1993) guidelines values for drinking water.

\section{GIS-analysis}

The spatial analysis of various physico-chemical parameters was carried out using the $\operatorname{ArcGIS}^{\circledR} 10$ software. In order to interpolate the data spatially and to estimate values between measurements, an inverse distance weighed (IDW) algorithm was used. The IDW technique calculates a value for each grid node by examining surrounding data points that lie within a user-defined search radius (Burrough and McDonnell 1998). All of the data points are used in the interpolation process and the node value is calculated by averaging the weighted sum of all the points.

\section{Results and discussion}

The quality standards for drinking water have been specified by the World Health Organization (WHO) in 2004. The behavior of major ions ( $\mathrm{Ca}, \mathrm{Mg}, \mathrm{Na}, \mathrm{K}, \mathrm{HCO}_{3}, \mathrm{SO}_{4}$, $\mathrm{Cl}$ ) and important physico-chemical parameters such as $\mathrm{pH}$, electrical conductivity (EC), total dissolved solids (TDS), and total hardness (TH) and the suitability of groundwater in the study area are discussed below.

Drinking suitability

The analytical results have been evaluated to ascertain the suitability of groundwater in the study area for drinking and agricultural uses. The analytical results for all the parameters for the groundwater samples in the study area are presented in the Table 1.

$\mathrm{pH}$

$\mathrm{pH}$ is a measure of the balance between the concentration of hydrogen ions and hydroxyl ions in water. The $\mathrm{pH}$ of water provides vital information in many types of 
Table 1 Physico-chemical characteristics of groundwater in the study area

\begin{tabular}{|c|c|c|c|c|c|c|c|c|c|c|c|}
\hline Sample no. & $\mathrm{pH}$ & $\mathrm{EC}(\mu \mathrm{mhos} / \mathrm{cm})$ & TDS (mg/l) & $\mathrm{TH}(\mathrm{mg} / \mathrm{l})$ & $\mathrm{Ca}(\mathrm{mg} / \mathrm{l})$ & $\operatorname{Mg}(\mathrm{mg} / \mathrm{l})$ & $\mathrm{Na}(\mathrm{mg} / \mathrm{l})$ & $\mathrm{K}(\mathrm{mg} / \mathrm{l})$ & $\mathrm{HCO}_{3}(\mathrm{mg} / \mathrm{l})$ & $\mathrm{SO}_{4}(\mathrm{mg} / \mathrm{l})$ & $\mathrm{Cl}(\mathrm{mg} / \mathrm{l})$ \\
\hline 1 & 5.69 & 340 & 284 & 544 & 42.4 & 106.4 & 17.2 & 8.1 & 148 & 0.07 & 52 \\
\hline 2 & 6.08 & 410 & 304 & 154 & 66.4 & 6.3 & 25.3 & 7.2 & 220 & 0.08 & 34 \\
\hline 3 & 6.31 & 1,020 & 642 & 332 & 1147.4 & 11.2 & 79.5 & 10.8 & 490 & 0.09 & 92 \\
\hline 4 & 5.23 & 125 & 130 & 404 & 22.4 & 84.6 & 6.1 & 2.2 & 110 & 0.00 & 12 \\
\hline 5 & 5.75 & 400 & 318 & 382 & 152.8 & 61.2 & 31.6 & 8.4 & 170 & 0.11 & 42 \\
\hline 6 & 6.35 & 800 & 592 & 244 & 92 & 3.4 & 99 & 10.9 & 370 & 0.00 & 92 \\
\hline 7 & 5.79 & 64 & 94 & 88 & 30.4 & 2.9 & 1.8 & 0.4 & 60 & 0.02 & 500 \\
\hline 8 & 5.87 & 69 & 100 & 94 & 18.4 & 11.7 & 2.6 & 0.8 & 80 & 0.08 & 12 \\
\hline 9 & 6.45 & 600 & 354 & 492 & 72.8 & 75.3 & 45.3 & 0.8 & 290 & 0.16 & 72 \\
\hline 10 & 6.9 & 260 & 198 & 142 & 45.8 & 6.8 & 12.3 & 3.8 & 170 & 0.00 & 32 \\
\hline 11 & 6.86 & 270 & 235.5 & 156 & 40.8 & 13.1 & 5.8 & 5.1 & 200 & 0.09 & 18 \\
\hline 12 & 6.51 & 690 & 460 & 186 & 43.2 & 19.0 & 73.5 & 1.5 & 310 & 0.19 & 80 \\
\hline 13 & 6.52 & 890 & 595.4 & 266 & 53.6 & 32.1 & 1.8 & 10.1 & 330 & 0.01 & 132 \\
\hline 14 & 6.3 & 570 & 477 & 162 & 51.2 & 8.3 & 50 & 11.2 & 310 & 0.04 & 56 \\
\hline 15 & 6.53 & 470 & 322 & 208 & 72 & 6.8 & 27.1 & 2.1 & 290 & 0.04 & 28 \\
\hline 16 & 6.16 & 350 & 294.2 & 136 & 52 & 1.5 & 27.9 & 3.8 & 190 & 0.04 & 34 \\
\hline 17 & 6.52 & 420 & 434 & 184 & 73.6 & 4.4 & 26.1 & 8.3 & 240 & 0.06 & 52 \\
\hline 18 & 6.57 & 500 & 341.2 & 236 & 56 & 23.3 & 41.1 & 3.8 & 290 & 0.19 & 40 \\
\hline 19 & 6.62 & 430 & 269.4 & 194 & 58.4 & 11.7 & 14.3 & 5.9 & 210 & 0.02 & 22 \\
\hline 20 & 5.46 & 170 & 184 & 70 & 17.6 & 6.3 & 17.8 & 2.8 & 120 & 0.18 & 22 \\
\hline 21 & 5.86 & 2,200 & 1,898.6 & 424 & 83.2 & 52.5 & 272.5 & 9.8 & 110 & 0.76 & 540 \\
\hline 22 & 6.5 & 260 & 201.4 & 238 & 54.4 & 24.8 & 10.2 & 2.4 & 170 & 0.19 & 18 \\
\hline Min & 5.23 & 64 & 94 & 70 & 17.6 & 1.5 & 1.8 & 0.4 & 60 & 0.00 & 12 \\
\hline Max & 6.9 & 2,200 & 1,898.6 & 544 & $1,147.4$ & 106.4 & 272.5 & 11.2 & 490 & 0.76 & 540 \\
\hline Mean & 6.2 & 514.0 & 396.8 & 242.5 & 106.7 & 26.1 & 40.4 & 5.5 & 221.7 & 0.1 & 90.1 \\
\hline SD & 0.4 & 453.6 & 369.7 & 132.6 & 234.3 & 30.2 & 58.2 & 3.7 & 105.2 & 0.2 & 142.6 \\
\hline
\end{tabular}

$S D$ standard deviation

geochemical equilibrium or solubility calculations (Hem 1985). The limit of $\mathrm{pH}$ value for drinking water is specified as 6.5-8.5 (WHO 2004; ISI 1993). The pH value of most of the groundwater samples in the study area varies from 5.2 to 6.8 (Fig. 3a), which clearly shows that the groundwater in the study area is slightly acidic in nature. This may be attributed to the anthropogenic activities like sewage disposal and use of fertilizers in the highly populated coastal segment of the study area followed by natural phenomenon like intrusion of brackish water into the sandy aquifers, which initiates the weathering process of underlain geology.

\section{Electrical conductivity (EC)}

Electrical conductivity is a measure of water capacity to convey electric current. The most desirable limit of EC in drinking water is prescribed as $1,500 \mu \mathrm{mhos} / \mathrm{cm}$ (WHO 2004). The $\mathrm{EC}$ of the groundwater is varying from 64.02 and $2199.57 \mu \mathrm{mhos} / \mathrm{cm}$ with an average value of $514 \mu \mathrm{mhos} / \mathrm{cm}$ (Fig. 3b). Higher EC in the study area indicates the enrichment of salts in the groundwater. The value of electrical conductivity may be an approximate index of the total content of dissolved substance in water. It depends upon temperature, concentration and types of ions present (Hem 1985). The EC can be classified as type I, if the enrichments of salts are low $(\mathrm{EC}<1,500 \mu \mathrm{mhos} / \mathrm{cm})$; type II, if the enrichment of salts are medium (EC 1,500 and 3,000 $\mu \mathrm{mhos} / \mathrm{cm}$ ); and type III, if the enrichments of salts are high $(\mathrm{EC}>3,000 \mu \mathrm{mhos} / \mathrm{cm})$. According to the above classification of EC, $96 \%$ of the total groundwater samples come under the type I (low enrichment of salts) and $4 \%$ under type II (medium enrichment of salts). The effect of saline intrusion may be the reason for medium enrichment of EC in the study area. The effect of $\mathrm{pH}$ may also increase the dissolution process, which eventually increases the $\mathrm{EC}$ value.

Total dissolved solids (TDS)

According to WHO specification TDS up to $500 \mathrm{mg} / \mathrm{l}$ is the highest desirable and up to $1,500 \mathrm{mg} / \mathrm{l}$ is maximum 


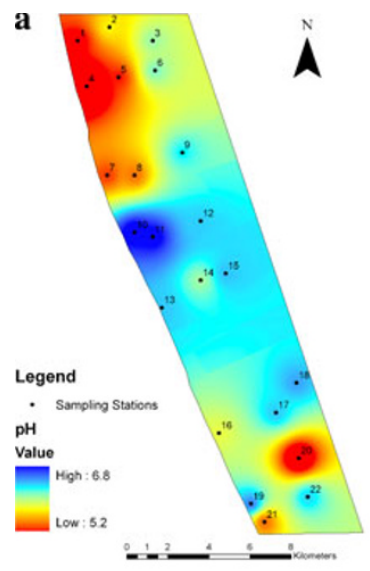

b

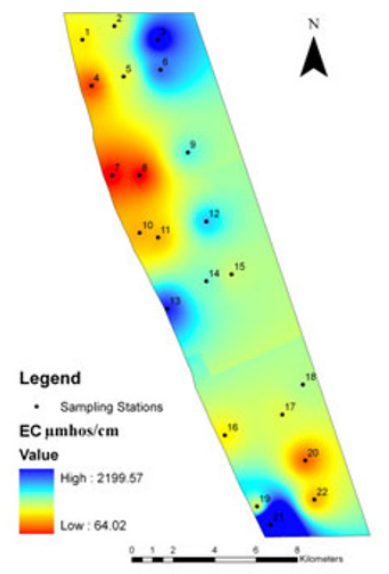

e

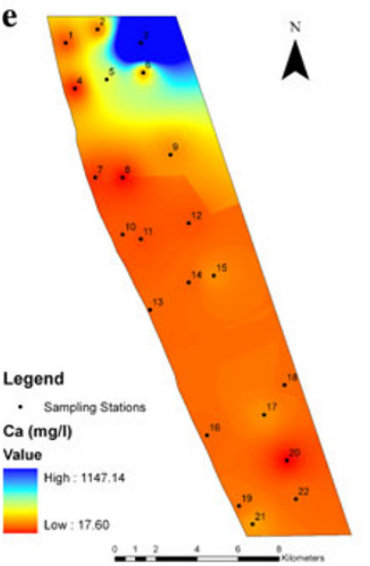

i

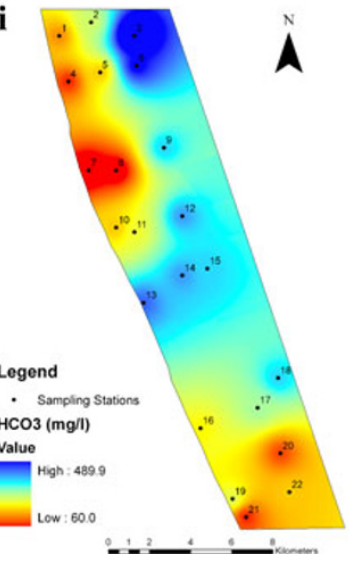

$\mathbf{f}$

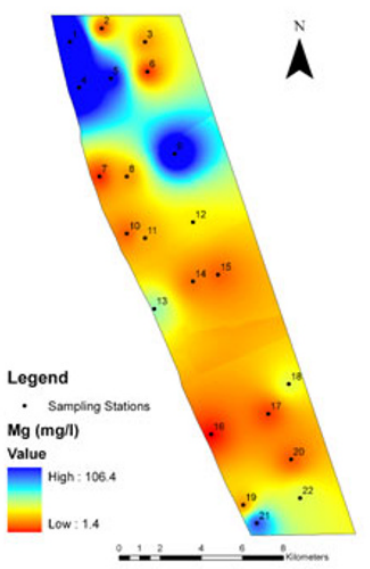

$\mathbf{j}$

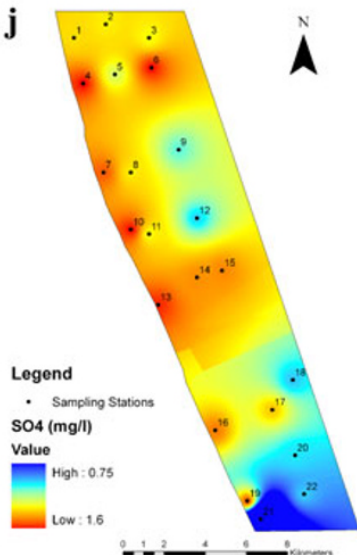

c
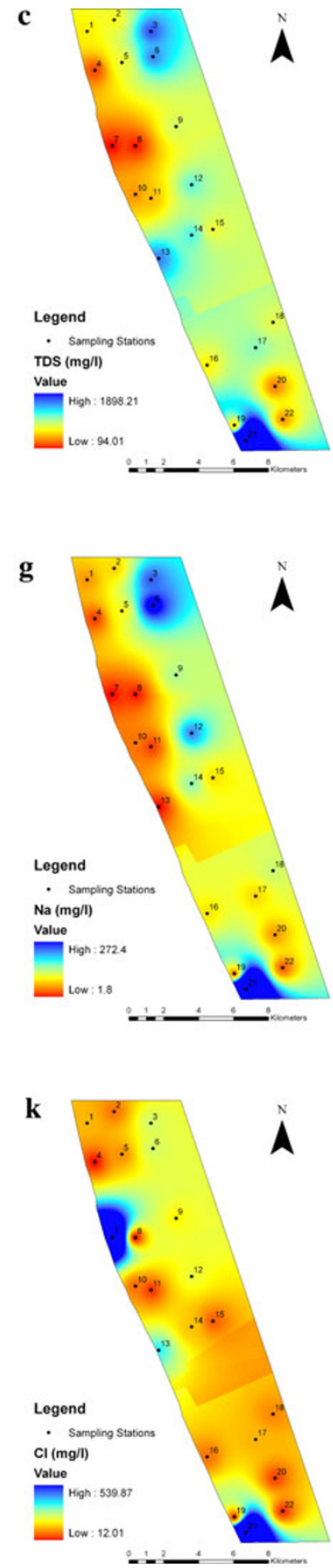

Fig. 3 a $\mathrm{pH}$ map of the study area, b EC map of the study area, c TDS map of the study area, $\mathbf{d}$ TH map of the study area, e Ca map of the study area, $\mathbf{f ~ M g}$ map of the study area, $\mathbf{g} \mathrm{Na}$ map of the study

permissible. In the study area the TDS value varies between a minimum of $94.01 \mathrm{mg} / \mathrm{l}$ and a maximum of $1,898.21 \mathrm{mg} / 1$ (Fig. 3c), indicating that most of the groundwater samples lies within the maximum permissible limit. According to the Davis and De Wiest (1966)
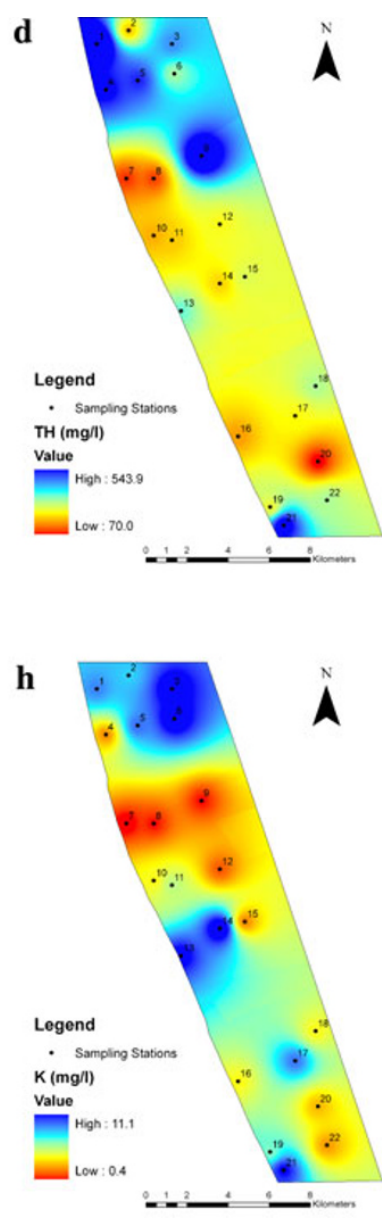

area, $\mathbf{h ~ K}$ map of the study area, $\mathbf{i} \mathrm{HCO}_{3}$ map of the study area, $\mathbf{j} \mathrm{SO}_{4}$ map of the study area, $\mathbf{k ~} \mathrm{Cl}$ map of the study area

(Table 2) classification of groundwater based on TDS, $82 \%$ of the total groundwater samples are desirable for drinking (TDS $<500 \mathrm{mg} / \mathrm{l}$ ), $14 \%$ permissible for drinking $(500-1,000 \mathrm{mg} / \mathrm{l})$ and $4 \%$ is suitable for irrigation purposes. High concentration of TDS in the groundwater 
Table 2 Classification of groundwater based on TDS (Davis and De Wiest 1966)

\begin{tabular}{lll}
\hline TDS $(\mathrm{mg} / \mathrm{l})$ & Water type & $\%$ of samples \\
\hline$<500$ & Desirable for drinking & 82 \\
$500-1,000$ & Permissible for drinking & 14 \\
$<3,000$ & Useful for irrigation & 4 \\
$>3,000$ & Unfit for drinking and irrigation & - \\
\hline
\end{tabular}

sample is due to leaching of salts from soil and also domestic sewage may percolate into the groundwater, which may lead to increase in TDS values.

Total hardness $(\mathrm{TH})$

The total hardness is varying from 70 to $543.9 \mathrm{mg} / \mathrm{l}$ (Fig. 3d). Groundwater of the entire study area lies within the maximum permissible limit prescribed by ISI. Sawyer and McCarty (1967) classified groundwater, based on TH, as ground water with $\mathrm{TH}<75,75-150,150-300$ and $>300 \mathrm{mg} / \mathrm{l}$, designated as soft, moderately hard, hard and very hard, respectively (Table 3). According to the above categorization, only $4.54 \%$ of the total groundwater samples are soft; $18.18 \%$ belongs to moderately hard; $50 \%$ belongs to hard and the remaining $27.27 \%$ comprises very hard water. The analytical result indicates the water in the study area is hard to very hard. The hardness of the water is due to the presence of alkaline earths such as calcium and magnesium. The drinking water quality is evaluated by comparing with the specifications of TH and TDS set by the World Health Organization and Indian standards (Table 4).

\section{Calcium and magnesium $(\mathrm{Ca}$ and $\mathrm{Mg})$}

Calcium and magnesium are the most abundant elements in the natural surface and groundwater and exist mainly as bicarbonates and to a lesser degree in the form of sulfate and chloride. $\mathrm{Ca}^{2+}$ concentrations are varying from 17.60 to $1,147.14 \mathrm{mg} / \mathrm{l}$ (Table 4; Fig. 3e). Relatively, the higher concentration of $\mathrm{Ca}^{2+}$ observed is $1,147.14 \mathrm{mg} / \mathrm{l}$ from the groundwater sample 3 . The rest of the groundwater samples show $\mathrm{Ca}^{2+}$ from 18.4 to $153 \mathrm{mg} / \mathrm{l}$. The desirable limit of calcium concentration for drinking water is specified as $75 \mathrm{mg} / \mathrm{l}$ (ISI 1993) which shows that few groundwater samples fall beyond the permissible limit. Only $5 \%$ of the groundwater samples taken from study area have crossed the maximum permissible limit of $200 \mathrm{mg} / \mathrm{l}$ for calcium but $9 \%$ are above the desirable limit. The higher $\mathrm{Ca}^{2+}$ content can cause abdominal ailments and is undesirable for domestic uses as it causes encrustation and scaling. Magnesium content is varying from 1.4 to $106.4 \mathrm{mg} / \mathrm{l}$ (Table 1 ;
Fig. 3f). The maximum permissible limit of $\mathrm{Mg}^{2+}$ concentration of drinking water is specified as $100 \mathrm{mg} / \mathrm{l}$ (ISI 1993) and $150 \mathrm{mg} / \mathrm{l}$ (WHO 2004). Sample number 1 exceeds the ISI limit as it shows a value of $106.4 \mathrm{mg} / \mathrm{l}$.

Sodium and potassium ( $\mathrm{Na}$ and $\mathrm{K})$

Sodium ranks sixth among the elements in order of abundance and is present in most of natural waters. Sodium is generally found in lower concentration than $\mathrm{Ca}^{2+}$ and $\mathrm{Mg}^{2+}$ in freshwater. The concentration of $\mathrm{Na}^{+}$is varied from 1.8 to $272.4 \mathrm{mg} / \mathrm{l}$. The maximum permissible limit of sodium is $200 \mathrm{mg} / \mathrm{l}$ and it reveals that few samples are exceeding the permissible limit of WHO and ISI (Table 4; Fig. 3g). The intake of high level of $\mathrm{Na}^{+}$causes increased blood pressure, arteriosclerosis, oedema and hyperosmolarity. Groundwater with high Na content is not suitable for agricultural use as it tends to deteriorate the soil.

Potassium is a naturally occurring element; however, its concentration remains quite lower compared with $\mathrm{Ca}, \mathrm{Mg}$ and $\mathrm{Na}$. Its concentration in drinking waters seldom reaches $20 \mathrm{mg} / \mathrm{l}$. The concentration of $\mathrm{K}^{+}$is observed between 0.4 and $11.1 \mathrm{mg} / \mathrm{l}$ from the groundwater (Fig. 3h). The maximum permissible limit of potassium in the drinking water is $12 \mathrm{mg} / \mathrm{l}$ and it was found that all the samples are below the permissible limit of WHO (Table 4). In comparison with $\mathrm{Na}^{+}$, the low concentration of $\mathrm{K}^{+}$is due to the high resistance of potash feldspars to chemical weathering in the study area.

\section{Bicarbonate $\left(\mathrm{HCO}_{3}\right)$}

The value of $\mathrm{HCO}_{3}$ is observed from 60 to $489.9 \mathrm{mg} / \mathrm{l}$ (Fig. 3i), which is the dominant ion, except in the groundwater, occurring near the coast (Table 1). The higher concentration of $\mathrm{HCO}_{3}$ in the water points to the dominance of mineral dissolution (Stumm and Morgan 1996).

\section{Sulfate $\left(\mathrm{SO}_{4}\right)$}

Sulfate is one of the major anion occurring in natural waters. The upper limit for sulfate concentration for drinking water is $150 \mathrm{mg} / \mathrm{l}$ (ISI 1993). The sulfate concentration in the study area ranges between 0.75 and $1.6 \mathrm{mg} / \mathrm{l}$ (Fig. 3j) with an average value of $0.76 \mathrm{mg} / \mathrm{l}$ indicating that all samples fall within the desirable limit.

\section{Chloride $(\mathrm{Cl})$}

The origin of chloride in groundwater may be from diverse sources such as weathering, leaching of sedimentary rocks and soils, intrusion of saltwater, windblown salt in 
Table 3 Sawyer and McCarty's classification of groundwater based on hardness

\begin{tabular}{lllr}
\hline $\begin{array}{l}\text { Total hardness as } \\
\mathrm{CaCO}_{3}(\mathrm{mg} / \mathrm{l})\end{array}$ & Water type & $\begin{array}{l}\text { Range (no. of } \\
\text { samples) }\end{array}$ & Percent \\
\hline$<75$ & Soft & $70(1$ sample $)$ & 4.55 \\
$75-150$ & Moderately & $88-142$ (4 samples) & 18.18 \\
& hard & & \\
$150-300$ & Hard & $154-266(11$ samples $)$ & 50.00 \\
$>300$ & Very hard & $332-544(6$ samples $)$ & 27.27 \\
\hline
\end{tabular}

precipitation, domestic and industrial waste discharges, municipal effluents, etc. (Karanth 1987). In the study area, the concentration of chloride is between 12.01 and $539.87 \mathrm{mg} / \mathrm{l}$ (Fig. 3k). Relatively, the higher concentration of $\mathrm{Cl}$ is observed from the groundwater sample 21. The Desirable limit of chloride for drinking water is specified as $250 \mathrm{mg} / \mathrm{l}$ (ISI 1993; Table 4). The excess of chloride in the water is usually taken as an index of pollution and considered as tracer fro groundwater contamination (Loizidou and Kapetanios 1993). In natural waters, the concentration of $\mathrm{Cl}$ bears strong correlation with the $\mathrm{Na}$ content and specific conductance. Chloride determinations may serve to indicate the intrusion of waters of different composition or to trace and measure rates and volumes of water mass movements.

\section{Hydro-geochemical facies}

Most natural water can be represented as solution of three cationic constituents, viz., $\mathrm{Ca}^{2+}, \mathrm{Mg}^{2+}$ and alkaline metals and of three anionic constituents viz., $\mathrm{SO}_{4}{ }^{2-}, \mathrm{Cl}^{-}$and those contributing to alkalinity, i.e., $\mathrm{CO}_{3}{ }^{2-}$ and $\mathrm{HCO}_{3}{ }^{-}$. Therefore, linear plots are most suitable for the representation of groundwater composition. The modified trilinear diagram was presented by Piper (1944). The diagram consists of three distinct fields-two triangular fields and one diamond-shaped field. Different groundwater can be identified by their position in the diamond field. Cations expressed as percentages of total cations in meq/l plot as a single point on the left triangle while anions plot in the right triangle. Similarities and differences among groundwater samples can be revealed from the trilinear because water of similar qualities will tend to plot together as groups. Distinct groundwater qualities can be quickly distinguished by their plotting in certain areas of the diamond field. The analytical values obtained from the groundwater samples are plotted on Piper trilinear diagram to understand the hydrochemical regime of the study area. The Piper trilinear diagram for the groundwater samples is presented in the Fig. 4, which clearly explains the variations of cation and anion concentration in the study area. The diamond-shaped field of piper diagram is further divided into four classes, namely $\mathrm{Ca}^{2+}-\mathrm{Mg}^{2+}-\mathrm{Cl}^{-}-\mathrm{SO}_{4}{ }^{2-}, \mathrm{Na}^{+}-\mathrm{K}^{+}-\mathrm{Cl}^{-}-\mathrm{SO}_{4}{ }^{2-}$, $\mathrm{Na}^{+}-\mathrm{K}^{+}-\mathrm{Cl}^{-}-\mathrm{HCO}_{3}$ and $\mathrm{Ca}^{2+}-\mathrm{Mg}^{2+}-\mathrm{HCO}_{3}{ }^{-}$. In the study area majority of samples belong to the $\mathrm{Ca}^{2+}-\mathrm{Mg}^{2+}$ $\mathrm{HCO}_{3}{ }^{-}$type and in the post monsoon period there is a dominance of $\mathrm{Ca}^{2+}-\mathrm{Mg}^{2+}$ type water.

\section{Irrigation suitability}

Salinity indices such as sodium percentage ( $\mathrm{Na} \%)$, sodium absorption ratio (SAR) and permeability index (PI) are important parameters for determining the suitability of groundwater for agricultural uses.

\section{Sodium percent $(\mathrm{Na} \%)$}

The sodium in irrigation waters is usually denoted as percent of sodium. According to Wilcox (1955), in all natural
Table 4 Groundwater samples of the study area exceeding the permissible limits prescribed by WHO (2004) and ISI (1993) for drinking purpose

Units $=\mathrm{mg} / \mathrm{l}$

\begin{tabular}{|c|c|c|c|c|c|c|}
\hline \multirow[t]{2}{*}{ S1 no. } & \multirow[t]{2}{*}{$\begin{array}{l}\text { Water quality } \\
\text { parameters }\end{array}$} & \multicolumn{2}{|c|}{$\begin{array}{l}\text { WHO International } \\
\text { Standards } 2004\end{array}$} & \multicolumn{2}{|c|}{$\begin{array}{l}\text { Indian Standard } \\
\text { (ISI 10500, 1993) }\end{array}$} & \multirow[t]{2}{*}{$\begin{array}{l}\text { Range in the } \\
\text { study area }\end{array}$} \\
\hline & & $\begin{array}{l}\text { Most desirable } \\
\text { limit }\end{array}$ & $\begin{array}{l}\text { Max. allowable } \\
\text { limit }\end{array}$ & $\begin{array}{l}\text { Highest } \\
\text { desirable }\end{array}$ & $\begin{array}{l}\text { Max. } \\
\text { permissible }\end{array}$ & \\
\hline 1 & $\mathrm{pH}$ & 6.5 & 8.5 & $6.5-8.5$ & $6.5-9.5$ & $5.2-6.8$ \\
\hline 2 & $\mathrm{EC}(\mu \mathrm{mhos} / \mathrm{cm})$ & 1400 & - & - & - & $64-2,200$ \\
\hline 3 & TDS & 500 & 1,500 & 500 & 2,000 & $94-1,898.6$ \\
\hline 4 & $\mathrm{TH}\left(\right.$ as $\left.\mathrm{CaCO}_{3}\right)$ & 100 & 500 & 300 & 600 & $70-544$ \\
\hline 5 & $\mathrm{Ca}^{2+}$ & 75 & 200 & 75 & 200 & $17.6-1,147.4$ \\
\hline 6 & $\mathrm{Mg}^{2+}$ & 50 & 150 & 30 & 100 & $1.5-106.4$ \\
\hline 7 & $\mathrm{Na}^{+}$ & - & 200 & - & 200 & $1.8-272.5$ \\
\hline 8 & $\mathrm{~K}^{+}$ & - & 12 & - & - & $0.4-11.2$ \\
\hline 9 & $\mathrm{CO}_{3}{ }^{2-}$ & - & - & - & - & - \\
\hline 10 & $\mathrm{HCO}_{3}^{-}$ & - & - & - & - & $60-490$ \\
\hline 12 & $\mathrm{SO}_{4}{ }^{2-}$ & 200 & 400 & 200 & 400 & $0-0.76$ \\
\hline 11 & $\mathrm{Cl}^{-}$ & 200 & 600 & 250 & 1,000 & $12-540$ \\
\hline
\end{tabular}


Fig. 4 Piper plot describing hydrogeochemical facies of the study area

\section{A - Calcium type \\ B - No Dominant \\ C - Magnesium type \\ D - Sodium type \\ E - Bicarbonate type \\ F - Sulphate type \\ G - Chloride type}

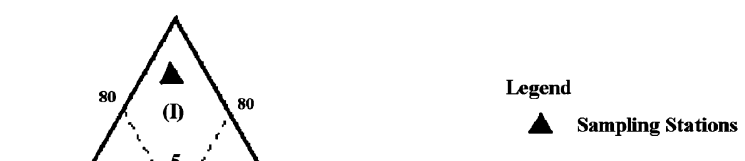

(I) $\mathrm{Ca}-\mathrm{Mg}-\mathrm{Cl}-\mathrm{SO} 4$
(II) $\mathrm{Na}-\mathrm{K}-\mathrm{Cl}-\mathrm{SO} 4$
(III) $\mathrm{Na}-\mathrm{K}-\mathrm{HCO} 3$
(IV) $\mathrm{Ca}-\mathrm{Mg}-\mathrm{HCO} 3$

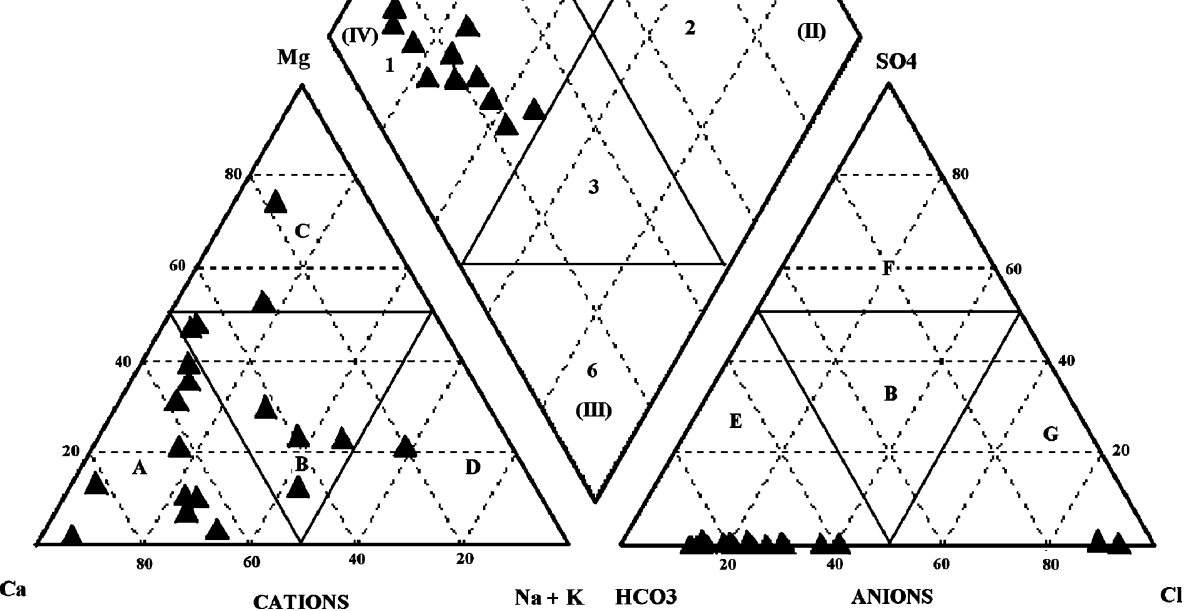

waters $\mathrm{Na} \%$ is a common parameter to assess its suitability for irrigational purposes. The sodium percent $(\mathrm{Na} \%)$ values was obtained by using the following equation:

$\mathrm{Na} \%=\mathrm{Na}^{+} \times 100 /\left[\mathrm{Ca}^{2+}+\mathrm{Mg}^{2+}+\mathrm{Na}^{+}+\mathrm{K}^{+}\right]$

where all ionic concentrations are expressed in meq/l. The Wilcox diagram relating sodium percent and total concentration shows that $95.4 \%$ of the groundwater samples fall in the field of good to permissible and $4.6 \%$ of the groundwater samples fall in the field of doubtful for irrigation and no samples fall in the unsuitable category (Fig. 5; Table 5).

\section{Sodium adsorption ratio (SAR)}

Sodium adsorption ratio (SAR) is a measure of the suitability of water for use in agricultural irrigation, because sodium concentration can reduce the soil permeability and soil structure (Todd 1980). SAR is a measure of alkali/ sodium hazard to crops and it was estimated by the following formula:

$\mathrm{SAR}=\mathrm{Na} /[(\mathrm{Ca}+\mathrm{Mg}) / 2]^{0.5}$

where sodium, calcium, and magnesium are in meq/l. The SAR value of water for irrigation purposes has a significant relationship with the extent to which sodium is absorbed by the soils. Irrigation using water with high SAR values may require soil amendments to prevent long-term damage to the soil, because the sodium in the water can displace the calcium and magnesium in the soil. This will cause a decrease in the ability of the soil to form stable aggregates and loss of soil structure. This will also lead to a decrease in infiltration and permeability of the soil to water leading to problems with crop production.

The calculated values of SAR in the study area vary between 0.28 and 33.08 (Table 6). The classification of groundwater samples based on SAR values are shown in Table 7. The SAR values of all the samples are found with in the range of excellent to good category, except sample 21 (SAR value $>26$ ), which is found to be unsuitable for irrigation purpose. For rating irrigation waters the US salinity diagram was used, in which the SAR is plotted against EC. The USSL (1954) plot indicates that $9.1 \%$ of the groundwater samples fall in C1S1 (low salinity-low sodium type) and $72.7 \%$ of the samples fall in the C2S1 category. This reveals that the water type in the study area has medium salinity with low sodium content and it can be used for irrigation on all type of soil (Fig. 6). About $13.6 \%$ of the groundwater samples fall in the $\mathrm{C} 3 \mathrm{~S} 1$, indicating high salinity-high sodium type. Only $4.6 \%$ falls in the 


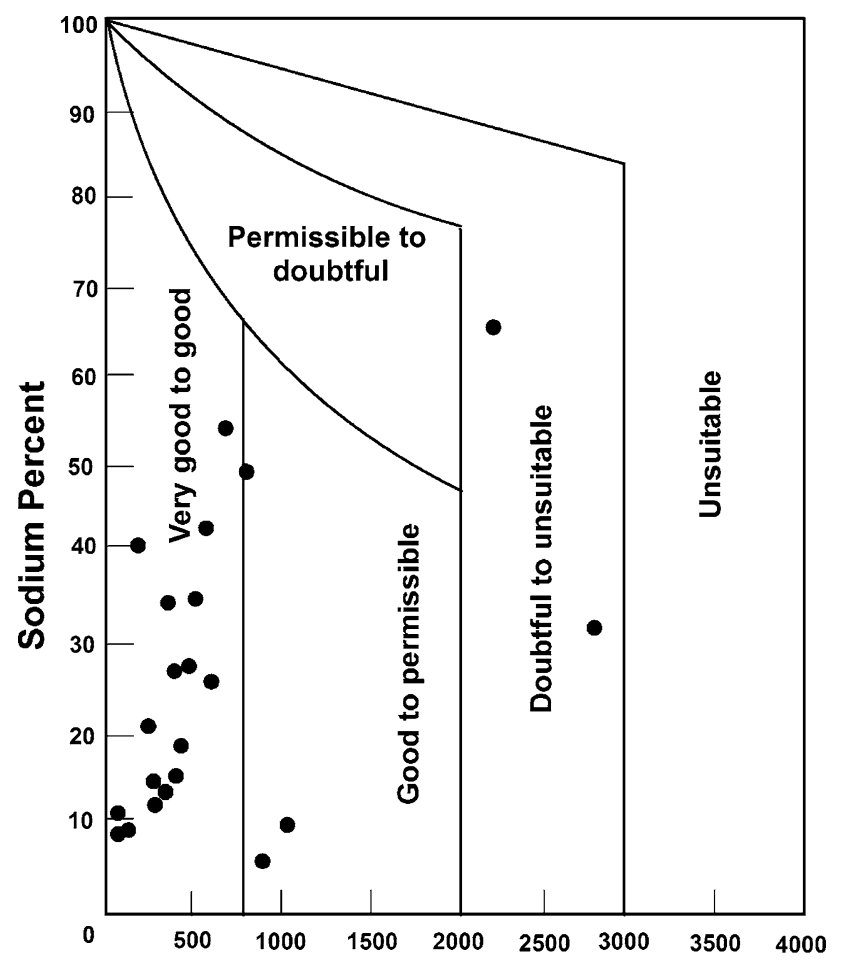

Electrical Conductivity (micromhos $/ \mathrm{cm}$ ) at $25^{\circ} \mathrm{C}$

Fig. 5 Classification of irrigation water quality, with respect to total salt concentration and sodium percent

Table 5 Classification of groundwater based on Na\% (Wilcox 1955)

\begin{tabular}{lll}
\hline Water quality & Sodium $(\%)$ & Percentage of samples \\
\hline Excellent & $<20$ & 50 \\
Good & $20-40$ & 31.8 \\
Permissible & $40-60$ & 13.6 \\
Doubtful & $60-80$ & 4.6 \\
Unsuitable & $>80$ & - \\
\hline
\end{tabular}

medium salinity to high sodium category (C3S2). This type of water can be used to irrigate salt tolerant and semi tolerant crops under favorable drainage condition.

Permeability index

Based on the permeability index (PI), a water suitability classification for irrigation water was developed by Doneen (1964). The PI was calculated by the following equation:

$\mathrm{PI}=\left[\mathrm{Na}+\left(\mathrm{HCO}_{3}\right)^{0.5}\right] \times 100 /[\mathrm{Na}+\mathrm{Ca}+\mathrm{Mg}]$

where all the ions are expressed in meq/l. The PI values in the study area vary from 1.93 to 28.14 during the post monsoon period (January 2009), with an average value of about 15.48 (Table 6). A classification based on PI was proposed by World Health Organization for assessing
Table 6 Computed values of Na\%, SAR, PI and MH in the study area

\begin{tabular}{lcccc}
\hline Sl. no. & Na\% & SAR & PI & MH \\
\hline 1 & 9.88 & 1.99 & 7.74 & 71.51 \\
2 & 24.05 & 4.2 & 15.98 & 8.69 \\
3 & 6.37 & 3.3 & 1.93 & 0.96 \\
4 & 5.29 & 0.83 & 9.53 & 79.06 \\
5 & 12.44 & 3.05 & 5.78 & 28.61 \\
6 & 48.22 & 14.33 & 11.14 & 3.57 \\
7 & 5.07 & 0.44 & 22.39 & 8.75 \\
8 & 7.77 & 0.67 & 27.82 & 38.8 \\
9 & 23.32 & 5.26 & 9.47 & 50.85 \\
10 & 17.9 & 2.4 & 20.8 & 12.93 \\
11 & 8.95 & 1.12 & 24.02 & 24.34 \\
12 & 53.59 & 13.18 & 14.44 & 30.5 \\
13 & 1.84 & 0.28 & 20.82 & 37.44 \\
14 & 41.44 & 9.17 & 17.33 & 13.89 \\
15 & 25.09 & 4.32 & 16.81 & 8.63 \\
16 & 32.76 & 5.4 & 18.14 & 2.73 \\
17 & 23.23 & 4.18 & 15.67 & 5.61 \\
18 & 33.08 & 6.53 & 15.11 & 29.41 \\
19 & 15.84 & 2.42 & 17.75 & 16.65 \\
20 & 39.98 & 5.15 & 28.14 & 26.42 \\
21 & 65.19 & 33.08 & 4.79 & 38.68 \\
22 & 11.11 & 1.62 & 15.02 & 31.3 \\
\hline & & & &
\end{tabular}

suitability of groundwater for irrigation purpose. According to the permeability index values, $90.9 \%$ of the samples falls under the class 3 (PI $<25 \%$ ) and only $9.1 \%$ belong to class 2 (PI ranged between 25 and $75 \%$ ) during the post monsoon period of 2009 .

Magnesium hazard

In most waters calcium and magnesium maintains a state of equilibrium. A ratio namely index of magnesium hazard was developed by Paliwal (1972). According to this, high magnesium hazard value $(>50 \%)$ has an adverse affect on the crop yield as the soil becomes more alkaline.

Magnesium ratio $=\mathrm{Mg}^{2+} \times 100 /\left(\mathrm{Ca}^{2+}+\mathrm{Mg}^{2+}\right)$

Table 7 Classification of groundwater based on SAR values (Todd 1959; Richards 1954)

\begin{tabular}{lll}
\hline Water quality & SAR values & No. of samples \\
\hline Excellent & $<10$ & 19 \\
Good & $10-18$ & 2 \\
Doubtful & $18-26$ & - \\
Unsuitable & $>26$ & 1 \\
\hline
\end{tabular}




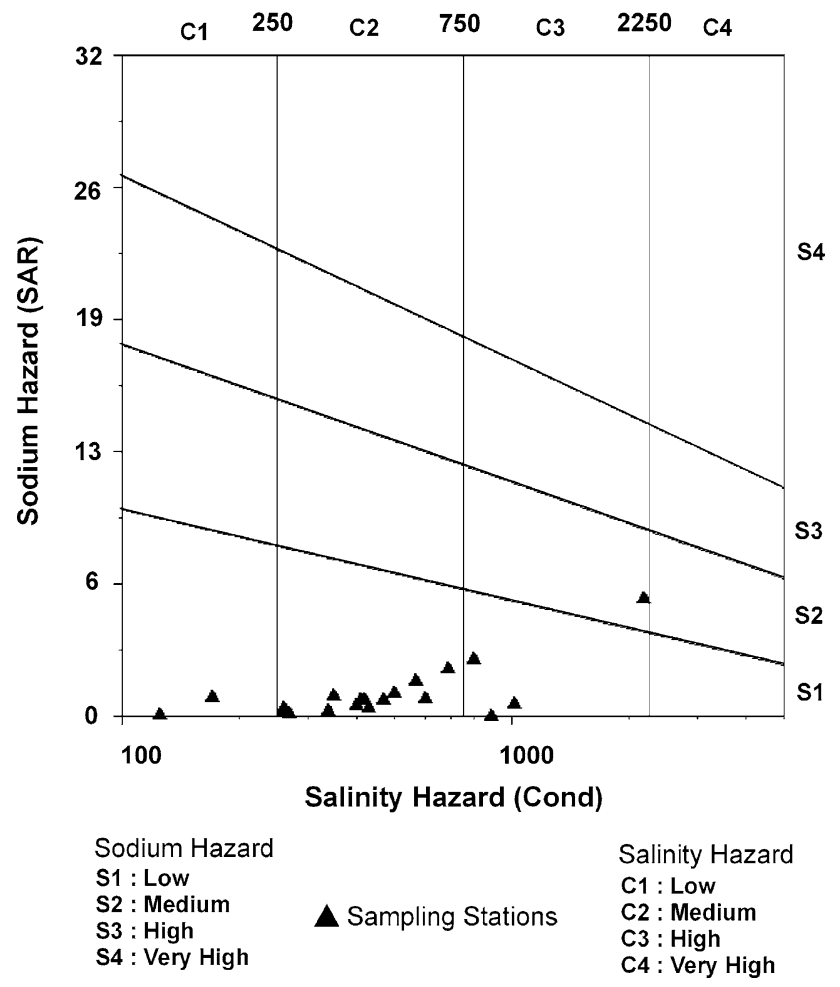

Fig. 6 Classification of irrigation water quality, with respect to salinity hazard and sodium hazard

In the study area the magnesium hazard values falls in the range of 2.73 to $79.06 \%$ (Table 6). In the study area, $86.36 \%$ of the samples collected showed MH ratio $<50 \%$ (suitable for irrigation) while $13.64 \%$ falls in the unsuitable category with magnesium hazard $>50 \%$. The evaluation illustrates that $13.64 \%$ samples can cause adverse effect on the agricultural yield.

\section{Conclusion}

Groundwater is an important source of drinking water for many people around the world. Contamination of groundwater generally results in poor drinking water quality, loss of water supply, high cleanup costs, high-cost alternative water supplies and potential health problem. In the present study, interpretation of hydrochemical analysis reveals that the groundwater in area is hard to very hard. The sequence of the abundance of the major cations and anions is $\mathrm{Ca}>\mathrm{Na}>\mathrm{Mg}>\mathrm{K}=\mathrm{HCO}_{3}>\mathrm{Cl}>\mathrm{SO}_{4}$. The dominant hydrochemical facies of groundwater in the study area is $\mathrm{Ca}-\mathrm{Mg}-\mathrm{HCO}_{3}$. Distribution of the groundwater samples in piper diagram reveals that all of the groundwater samples fall under the calcium-magnesium-bicarbonate category. In the study area there is a dominance of $\mathrm{Ca}^{2+}-\mathrm{Mg}^{2+}$ type water. Based on the TH and TDS of almost all samples, the groundwater from Alappuzha coastal stretch is found to be safe and suitable for drinking purposes. The majority of groundwater sources belong to $\mathrm{C} 2 \mathrm{~S} 1$, indicating medium salinity -low sodium water, which can be used for irrigation on all types of soil without danger of exchangeable sodium. Groundwater is immensely important to meet the human needs in the coastal areas of Alappuzha district. In spite of the pre-eminent position of groundwater for water supply in the coastal belt, it is surprising that no concrete efforts have been made to systematically assess the quantity and quality of this natural resource. Also the lack of knowledge stands in the way of formulation of any viable policy for the management of groundwater system of the coastal zone.

Acknowledgments The authors sincerely thank Prof. Abdulrahman I. Alabdulaaly, Editor-in-Chief, Applied Water Science, for his valuable suggestions in improving the revised manuscript. We thank the two anonymous reviewers for their valuable and constructive suggestions in bringing the manuscript to its present form.

Open Access This article is distributed under the terms of the Creative Commons Attribution License which permits any use, distribution, and reproduction in any medium, provided the original author(s) and the source are credited.

\section{References}

APHA (1995) Standard methods for the examination of water and waste water, 19th edn. American Public Health Association, Washington, DC

Babiker IS, Mohamed MAA, Hiyama T (2007) Assessing groundwater quality using GIS. Water Resour Manag 21:699-715

Basak P (1992) Kerala's water resources myths, facts and realities. Centre for Water Resources Development and Management, Kozhikode

Bear J (1979) Hydraulics of groundwater. McGraw-Hill International Book, New York

Burrough PA, McDonnell RA (1998) Principles of geographical information systems. Oxford University Press, Oxford, p 333

Central Ground Water Board (CGWB) (2007) Groundwater information booklet of Alappuzha district, Kerala state, pp 1-26

Davis SN, De Wiest RJM (1966) Hydrogeology, vol 463. Wiley, New York

Doneen LD (1964) Notes on water quality in agriculture. Water Science and Engineering, University of California, Davis

Foster SSD (1995) Groundwater for development: an overview of quality constraints. In: Nash $\mathrm{H}$, McCall GJH (eds) Groundwater quality (17th special report). Chapman \& Hall, London, pp 1-3

Foster S (1998) Groundwater assessing vulnerability and promotion protection of a threatened resource. In: Proceedings of the 8th Stockholm water symposium, Sweden, pp 79-90

Hem JD (1985) Study and interpretation of the chemical characteristics of natural waters, 3rd edn. USGS Water Supply Paper. 2254, pp 117-120

ISI (1993) Indian standard specification for drinking water. ISI 10500, New Delhi

Karanth KR (1987) Groundwater assessment, development and management. Tata McGraw Hill publishing Company Limited, New Delhi

Krishna Kumar S, Chandrasekar N, Seralathan P, Godson PrinceS, Magesh NS (2011) Hydrogeochemical study of shallow 
carbonate aquifers, Rameshwaram Island, India. Environ Monit Assess. doi:10.1007/s10661-011-2249-6

Loizidou M, Kapetanios EG (1993) Effect of leachate from landfills on underground quality. Sci Total Environ 128:69-81. doi: 10.1016/0048-9697(93)90180E

Magesh NS, Chandrasekar N (2011) Evaluation of spatial variations in groundwater quality by WQI and GIS technique: a case study of Virudunagar District, Tamil Nadu, India. Arab J Geosci. doi: 10.1007/s12517-011-0496-Z

Manjusree TM, Joseph Sabu, Thomas Jobin (2009) Hydrogeochemistry and groundwater quality in the coastal sandy clay aquifers of Alappuzha district, Kerala. J Geol Soc India 74:459-468

Sawyer GN, McCarthy, DL (1967) Chemistry of sanitary engineers, 2nd edn. Mc Graw Hill, New York, p 518

Nickson RT, McArthur JM, Shrestha B, Kyaw-Nyint TO, Lowrt D (2005) Arsenic and other drinking water quality issues, Muzaffargarh District, Pakistan. Appl Geochem 20:55-68

Paliwal KV (1972) Irrigation with saline water) [Z]. Monogram No. 2 (new series). IARI, New Delhi, p 198

Pawar NJ, Shaikh IJ (1995) Nitrate pollution of ground waters from shallow basaltic aquifers, Deccan trap Hydrologic Province, India. Environ Geol 25:197-204

Piper AM (1944) A graphical interpretation of water analysis. Trans Am Geophys Union 25:914-928
Richards LA (1954) Diagnosis and improvement of saline and alkaline soils [M]. U.S Department of Agriculture Hand Book. p 60

Schiavo MA, Havser S, Gusimano G, Gatto L (2006) Geochemical characterization of groundwater and submarine discharge in the south-eastern Sicily. Cont Shelf Res 26(7):826-834

Stumm W, Morgan JJ (1996) Aquatic chemistry. Wiley, New York, p 1022

Subramani T, Elango L, Damodarasamy SR (2005) Groundwater quality and its suitability for drinking and agricultural use in Chithar River Basin, Tamil Nadu, India. Environ Geol 47:1099-1110

Sujatha D, Reddy RB (2003) Quality characterization of groundwater in the south eastern parts of the Ranga Reddy district, Andhra Pradesh, India. Environ Geol 44(5):570-576

Todd DK (1959) Groundwater hydrology [M]. Wiley, p 535

Todd DK (1980) Groundwater hydrology [M], 2nd edn. Wiley, New York, p 535

USSL (1954) Diagnosis and improvement of saline and alkali soil. USDA Hand Book no. 60, Washington

Walton WC (1970) Groundwater resources evaluation. Mc Graw Hill Book Co, New York

WHO (2004) Guidelines for drinking water quality. World Health Organisation, Geneva

Wilcox LV (1955) Classification and use of irrigation waters. USD Circular No. 969, p 19 